\title{
Minority Protection in Proceedings for the Settlement of Disputes Between Shareholders
}

\author{
Nore Delanga
}

\begin{abstract}
"A limited company is more than a mere judicial entity, with a personality in law of its own: Behind it, or amongst it, there are individuals, with rights, expectations and obligations inter $s e^{\prime \prime}$. The competitive attitude of the member states of the EU (European Union), to become the most attractive for companies results in law reforms aiming at more flexible conflict between shareholders ${ }^{2}$. Besides, the economic objective of avoiding a company's dissolution, the English, Dutch, and Belgian exit proceedings ${ }^{3}$ for the settlement of disputes between shareholders set up a social objective: protecting the interests of the minority shareholder of a private limited company4. The paper consists of four chapters. The introduction lays out the necessity of buy-outs for shareholders of a private limited company. The first chapter describes the different facts justifying the buy-out of a shareholder on the basis of serious grounds. The second chapter presents the findings of a comparative research of the valuation of the shares transferred in an English, Dutch, and Belgian procedure. Finally, the conclusion summarises in which way the English, Dutch, and Belgian legal system protect the interests of the minority shareholder of a private limited company.
\end{abstract}

\section{Keywords}

Company law, settlement of disputes between shareholders, social objective of exit proceedings, unfair prejudice procedure, fairness of the price for compulsory transferred shares, reflective loss

Features of small and micro-enterprises and the majority rule in the general meeting of shareholders as point of departure in a (small or micro-) enterprise-up to 23 million enterprises in the EU (European Union) or $99 \%$ of all European enterprises are small and micro-enterprises ${ }^{5}$. In the Small Business Act (SBA) 2008, the European Commission recognizes the special role of small and micro-enterprises and in particular family-based enterprises, their typically local base, socially responsible attitudes and capacity to combine tradition with innovation. The first of the 10 SBA principles preconceives the creation of an environment within which entrepreneurs and family businesses can thrive and entrepreneurship is rewarded ${ }^{6}$.

Nonetheless, corporate governance codes focus primordially on the performance of managers' conduct in multinationals and pay little or no attention to the typical feature of small and micro-enterprises. Small and micro-enterprises are characterized by the influence of the private relationships between shareholders on their business .

In small and micro-enterprises, a small number of shareholders have set up the articles of association on the basis of mutual trust and confidence. Mostly but

aKatholike University, Belguim

Correspondent Author:

Nore Delang, Melijnlaan, 5, Zwijndrecht (Antwerp), Belgium E-mail: nore.delang@gmail.com 
not necessarily, the shareholders are related to each other. Moreover, these shareholders expect to be involved in the management of the small or micro-enterprise ${ }^{7}$.

Against this background, every decision in the general meeting of shareholders is taken conform the majority rule. The term majority rule is generally understood to mean that the will expressed by the majority of shareholders (the will in the shareholders' group) becomes by "force of number" the will imposed on the group (the will of the shareholders' group). A decision made by the general meeting is the consequence of a democratic rule, requiring a majority of $50 \%+1$ vote of all shares.

It is not necessary to hold more than $50 \%$ of the shares to control a private limited company. If shares are divided equally between three shareholders and two shareholders decide to cooperate, a majority is created and the third shareholder becomes a non-controlling one.

The democratic principle of majority rule results in a substantial power placed in the hands of those who control more than half of the votes at a shareholders' meeting, and results in the possibility of dissenting minorities ${ }^{8}$.

\section{TWO TYPES OF SHAREHOLDERS' CONFLICTS AND COMPARISON WITH A CONFLICT BETWEEN MANAGERS}

As a consequence of the majority rule, two kinds of conflict situations are possible. The conflict situation depends on the numbers of shares and the voting power of the shareholders.

The first type of shareholders' conflict follows from the difference in voting power between shareholders. A minority shareholder has to accept the majority rule, unless the majority abuse their controlling voting position at the expense of the minority shareholder. A “non-controlling” or minority shareholder may find himself locked in the company ${ }^{9}$.
The opposite is also possible: A majority shareholder can find himself obstructed in a blocked decision-making process when a minority shareholder abuses his position. For instance, if the continuation of the company requires a capital increase and a minority shareholder persists unreasonably to vote not in favor of the capital increase.

In the second type of shareholders' conflict, voting rights are equally divided (for example, in a joint venture). There is no majority or minority shareholder: None of the shareholders have a decisive vote nor control the decision-making process. Hence, a deadlock may occur, even if none of the shareholders abuse their position.

The long duration and changing environment may result in two shareholders, initially willing to cooperate, not being able to negotiate a business plan satisfactory to both ${ }^{10}$.

Thus, why are shareholders conflicts such a problem for the continuation of a small or micro-enterprise? Shareholders cannot shove up their conflict to someone else. In contrast, a serious and long-lasting disagreement between managers or between managers and shareholders can be solved through the fact that shareholders, as a group, have the last word. Managers can be dismissed against their will by shareholders for the reason that shareholders are the owners of the company who engage and discharge managers.

On the other hand, shareholders cannot replace one another. Therefore, a serious and long-lasting disagreement between shareholders can become a pressing problem for the continuation of a company.

\section{DISSOLUTION, AVOIDING DISSOLUTION THROUGH BUY-OUT AND THE PROCEEDINGS FOR THE SETTLEMENT OF DISPUTES BETWEEN SHAREHOLDERS}

When businesses, and often personal relations between shareholders, have broken down, and the court is incapable of enforcing reconstitution, the 
serious and long-lasting conflict between shareholders can be settled by shareholders putting an end to their cooperation. Therefore, a shareholder may demand the court to order the dissolution of a company, based on important grounds. Still, the grounds to obtain the voluntary dissolution of a company are restrictive, considering the profound and harsh consequences. Economically speaking, the dissolution and liquidation of a company is a sweeping measure.

However, providing for the possibility of a compulsory dissolution of the company force shareholders to consider other possibilities to settle their disputes. The threat of dissolution sometimes urges shareholders to agree about the buy-out of one of them.

During the negotiations, in order to settle a serious and long-lasting conflict between shareholders, one shall not have a strong position. Unlike a shareholder of a company listed on a stock exchange, a shareholder of a limited private company cannot sell his shares easily and at any time.

Moreover, a transfer of shares can be restricted by approval of the general meeting or a preferential subscription right (preemptive right) for the existing shareholders, as stated in a shareholders' agreement or the articles of association. Above all, due to the majority rule, shares with few voting rights and thus few influence in the decision-making process in a company, are less marketable.

As a consequence of these deficiencies, the only available buyers of the shares will offer only a minimal price.

Furthermore, it is shown that oppressed shareholders search to transfer their shares to the oppressing shareholder. As a respond to that, the oppressing shareholder has no interest in the shares and refuses the offer for sale or proposes an extremely discounted price. An oppressed shareholder would be better off with an exit proceeding, with a judge fixing the price.

Though, fixing a fair price in case of a shareholders' buy-out is not the only reason why the
Dutch and Belgian legislator introduced the proceedings for the settlement of disputes between shareholders. In the first place, the proceedings aim at avoiding dissolutions and thus avoiding economic loss.

In comparison with the dissolution, proceedings for the settlement of disputes between shareholders ran into a serious and long-lasting conflict is a less radical remedy. A shareholder of a Dutch or Belgian private limited company may order:

(1) The transfer of his own shares to a defending co-shareholder ${ }^{11}$ (exit proceeding);

(2) The transfer of shares hold by the defending co-shareholder to himself ${ }^{12}$ (expulsion proceeding).

These proceedings aim to solve the dispute between shareholders of a private limited company by means of a compulsory exit or expulsion in exchange for payment: If a shareholder can prove a serious ground why cooperation can no longer be expected, his demand for his own exit or his claim to expel another shareholder will be granted and the judge will appoint an expert to determine the price of the shares exchanged $^{13}$. Every shareholder can demand his own exit, whereas the expulsion of a co-shareholder can be ordered by one or more shareholders holding at least one third of the voting rights or one third of the share capital of the company.

Besides, solving a shareholders conflict by means of exit is one of the remedies, a British judge can pronounce in an unfair prejudice procedure ${ }^{14}$. Without a requirement for the percentage of voting rights or the share capital, any shareholder of a company can start a petition on the ground that:

(1) The company's affairs have been conducted or are being conducted in a manner that is unfairly prejudicial to the interests of (a part of) its members;

(2) Any actual or proposed act or omission of the company is or would be so prejudicial.

Albeit the scope of the unfair prejudice remedy is not limited to private companies with limited shares, shareholders of public limited companies hardly ever introduce an unfair prejudice procedure ${ }^{15}$. 


\section{EXIT PROCEEDINGS COMPARED TO THE UNFAIR PREJUDICE PROCEDURE}

Not only the Dutch and Belgian exit proceedings, but also the English unfair prejudice procedure provides for the purchase of the shares and an English judge assesses whether the interests of a petitioning shareholder are prejudiced by his co-shareholder(s).

While the Dutch and Belgian exit proceedings focus on one possible remedy, the unfair prejudice procedure foresees that the English court can make "Such order as it thinks fit for giving relief in respect of the matters complained of". The English court may, among other remedies, regulate the conduct of the company's affairs in the future, require the company to (not) do an act, authorize civil proceedings in the name and on behalf of the company, prohibit the company to change its articles of association or provide for the purchase of the shares of a (normally non-controlling) shareholder by co-shareholders or the company itself. An English court, however, cannot expel the defending shareholder, like the Dutch and Belgian court may do.

In contrast, the shareholder starts an exit proceeding under Dutch or Belgian law when his interests are prejudiced to such an extent that the continuation of his shareholding can no longer reasonably be expected from him and the Dutch or Belgian court may only grant the claim or not.

\section{THE SOCIAL OBJECTIVE OF EXIT PROCEEDINGS}

Besides the economic objective of avoiding a company's dissolution, the exit proceedings set up a social objective: protecting the (patrimonial) interests of the minority shareholder. Indisputably, this is a social goal aiming to give all shareholders a fair procedure. In order to achieve this social objective, the answers to the following two questions are crucial:

(1) Which facts does the court consider as serious grounds to exit or to expel a shareholder? (Chapter 1)

(2) And how does the court assess the fairness of the price to be paid for the compulsory transferred shares? (Chapter 2)

In what follows, the English, Dutch, and Belgian procedures are compared on these two points. The comparison intends to determine how the social objective of protecting the (patrimonial) interests of the minority shareholder can be achieved. Furthermore, the comparison aims to analyze which country protects the most the (patrimonial) interests of the minority shareholder.

\section{CHAPTER 1-WHICH FACTS ARE UNFAIRLY PREJUDICIAL AND CONSTITUTE SERIOUS GROUNDS TO EXIT A SHAREHOLDER}

The author assumes that achieving the social objective of protecting the (patrimonial) interests of the minority shareholder depends among others on the way of examining the facts that are granted as unfair prejudice or serious grounds to exit a company.

This chapter gives a brief overview of the English, Dutch, and Belgian framework. Furthermore, two kinds of cases are compared under English, Dutch, and Belgian law: To what extent a minority shareholder has the possibility to exit when a majority shareholder removes him from the manager's board (first case) or averts the assets of the business (second case)?

English, Dutch, and Belgian Legal Framework to Examine the Facts That May Grand a Shareholders' Claim to Exit

Under English law, a shareholder may exit in case of an unfair prejudice ${ }^{16}$. A court could grant a remedy when it thinks a prejudice to the company's affairs or one or more shareholders is not only prejudice per se, but also unfair. This is the test of unfairness a judge has to undertake. The test of whether the prejudice is unfair examines whether the harm suffered by a 
non-controlling shareholder is something he has the right to be protected from. A prejudice can be unfair even if controlling shareholders did not intend to harm the non-controlling shareholder(s).

Moreover, a lot of unfair prejudice cases are based on legitimate expectations or equitable considerations of a petitioning non-controlling shareholder. In this case, a judge verifies with a test of unfairness whether this expectation is legitimate or not.

Shareholders of a small company can have a concrete and unmistakable understanding of how the company must be ran, but draw up only a standard set of articles of association. On the other hand, if the foundations for the company's conduct is "adequately and exhaustively laid down in the articles of association”, ${ }^{17}$ a non-controlling shareholder cannot state that a company's act is unfairly prejudicial because of an informal agreement.

In 1989, the Dutch legislator introduced the proceedings for the settlement of disputes between shareholders of a Besloten Vennootschap by way of compulsory transfer of shares ${ }^{18}$. This is known under the Dutch name geschillenregeling. The proceedings consist of four distinctive proceedings: the expulsion proceedings, the proceedings for the compulsory transfer of voting rights, the exit proceedings, and price determination proceedings. With regard to the social goal, this paper will only focus on the last two proceedings.

A Dutch exit proceeding gives a shareholder the right to transfer his shares to co-shareholders or to the company if it appears that his interests are prejudiced by the conduct of his co-shareholder(s) or by the conduct of the company, to such an extent that the continuation of his shareholding can no longer reasonably be expected from him. The exit proceedings were developed for the oppressed shareholder who cannot sell his shares at a fair price.

Likewise the English unfair prejudice, a Dutch exit proceeding can be started against the company itself ${ }^{19}$. This is beneficial when the prejudicial conduct is caused by the company itself. Though, every now and then it will be complicated to distinguish between the company's behavior and the conduct of a controlling shareholder ${ }^{20}$. The petitioning shareholder must prove the causal link between the prejudicial conduct and his assertion that the continuation of his shareholding can no longer reasonably be expected from him.

An exit proceeding against the company itself can only be rewarded if the purchase of the company's own shares is possible on the basis of the imperative balance and liquidity tests ${ }^{21}$. In the situation that only the company caused the prejudicial conduct and the shareholder who wants to exit foresees that one of the two tests will not be met, the shareholder will be locked up in the company. Nevertheless, this shareholder may demonstrate that he has reasons to doubt the correctness of the policy of the company and start an inquiry proceeding. The inquiry proceeding cannot lead to a compulsory transfer of shares, but most of the inquiry proceedings end up with an amicable agreement in which a transfer of shares is approved by both parties.

In addition to the exit proceedings, the Dutch legislator introduced the price determination proceedings. When shareholders agree on the transfer itself, but argue about the valuation of shares and price-setting, they can demand the court to intervene and estimate the price.

As far as the Belgian exit proceedings are concerned, the legislator introduced the proceedings for the settlement of disputes between shareholders in 1995. There are three distinct proceedings: expulsion proceedings $\mathrm{s}^{22}$, proceedings for the compulsory transfer of voting rights, and exit proceedings ${ }^{23}$.

Every shareholder who can base his claim on well-founded, serious grounds can exit the company. Though, an exit proceeding against the company itself is not possible. The exit proceeding must be brought against a co-shareholder who is obliged to take over the shares at the price set by the court. Serious grounds are judged on account of the petitioning shareholder 
who wants to exit.

Belgian case law accepts three types of serious grounds. A serious ground can be: (1) serious default; (2) abuse of position of a shareholder; or (3) a serious and long-lasting disagreement between shareholders, such as a deadlock.

Not only abuse of position or serious default can be estimated as serious grounds to exit or to expel a shareholder, but also a serious disaccord between shareholders without either side having done something wrong or unfair. This broad field of application and the large amount of small and micro-enterprises clarify why in Belgium, the expulsion and exit proceedings are the mostly demanded proceedings in company law: The president of the commercial court acting in summary proceedings spends up to half of his time settling disputes between shareholders ${ }^{24}$.

What is more, over a period of almost 20 years, the Belgian proceedings for the settlement of disputes between shareholders became the most popular proceedings in Belgian company law of all time ${ }^{25}$.

\section{Case Compared: Dismissal of the Minority Shareholder as Director of the Manager's Board}

Suppose that four shareholders, all holding $25 \%$ of the shares, agree that they will always be director and will take all important decisions together. Three shareholders want to change the business plan, the other one votes against. The fourth shareholder wants to withdraw from business, but none of the other shareholders have enough money to buy his shares. And why would they do so? What is more, the other shareholders vote to keep all profits in the company and do not pay a dividend, while the fourth shareholder is suspecting them to embezzle money of the company and cook to accounts. He thinks it is in vain to defend his point at the board of directors and decide not to come anymore. At the end of the year, the other shareholders decide to discharge the board of directors and dismiss him as a director.

An English court can recognize informal agreements existing outside the articles of association. When a majority shareholder ignores without any reason the legitimate expectations of a non-controlling shareholder generated by informal agreements, the court may protect the non-controlling shareholder. Without legitimate expectations, a shareholder is not in the position to bring up his later discretionary removal from the board of directors by ordinary resolution in which a majority shareholder abuses the principle of majority rule.

It is generally accepted that the interests of a shareholder are unfairly prejudiced by his expulsion from the board in a quasi-partnership ${ }^{26}$, if no offer for the purchase of his shares was made ${ }^{27}$. For example, it could be expected that the return on investment would take the form of directors' compensations. Or it could also be necessary to take part in the board of directors to protect the non-controlling shareholders' interests. Therefore, the right to participate in the management can be seen as an informal agreement between shareholders of a quasi-partnership.

If the non-controlling shareholder can prove the existence of an informal agreement that guarantees his participation in the management and can prove that the removal as director from the management board is involuntary, the court can make "such order as it thinks fit for giving relief in respect of the matters complained of". The court may provide for the purchase of the shares of the non-controlling shareholder by the oppressing shareholder, with a fair price determined by an expert.

However, in the Larvin v Phoenix Office Supplies case $^{28}$, one of the three shareholders, Larvin, wanted to sell his shares to the others, while the three shareholders were also directors. Later on, Larvin refused to give up his managing responsibilities, but the other two shareholders treated him as having resigned as a director. Larvin offered to sell his shares, but the other two shareholders only wanted to buy his 
shares at a discounted value, due to their minority power.

Larvin claimed that he was unfairly prejudiced, because he was factually excluded from the management. As the company could be considered to be a quasi-partnership, Larvins' claim to be bought out at a price without discount should be granted. The Court of Appeal judged that the company was indeed a quasi-partnership. But there must be something more in order for an unfair prejudice to be applicable. Larvin would only become a director again in order to have access to the financial information about the company and receive a better price for the shares he wanted to sell. An order for the buy-out of Larvin on the basis of article 994 AC 2006 would be disproportionate. Therefore, his claim was dismissed.

And what if the petitioner himself had done something wrong? In the Grace v Biagioli case ${ }^{29}$, the petitioning shareholder was dismissed as a director. He claimed to be unfairly prejudiced by this act, and proved this by an agreement in which a seat as a director was guaranteed. But the petitioning shareholder had sought to buy a competing company. This act justified his removal as a director in breach of the agreement. Therefore, the prejudice done to the petitioning shareholder was not unfair.

It can be seen as standing case law in the Netherlands that the dismissal of a managing director who is also a shareholder can justify the exit of that shareholder ${ }^{30}$. This does not mean though that every dismissal as a director will lead to a successful exit proceeding.

A minority shareholder, who was dismissed as a director, could exit out of the company. The minority shareholder was never appointed as a director, but was de facto part of the board of directors for more than 16 years until the majority shareholder abused his majority position to dismiss him. The court considered that the confidence between both shareholders was breached, and thus granted the claim to exit ${ }^{31}$.

In the well-known Hooymans case $^{32}$, three brothers were the shareholders and directors in two Besloten Vennootschappen. Each brother held one third of the shares. Disagreements drove the three brothers apart. Two brothers used their majority to dismiss the third brother as a director. The third brother began a new company, competed with his brothers and introduced an exit proceeding. Taking into account the initial role of each brother as shareholder and as director, the court (in first and second instance) decided that the removal as a director prejudices the brother's interests to such an extent that the continuation of his shareholding could no longer reasonably be expected of him. The Dutch court attached less importance to the competitive activity than the English court in the Grace v Biagioli case.

In the Ruitenberg case $^{33}$, a shareholder was "honorably" dismissed as a director after a serious and long-lasting disagreement between the shareholders. The difference in understanding and ideas about the future of the company made a dismissal unavoidable. But a dismissal per se, without other additional circumstances, is not enough to force a co-shareholder to pay for one's exit.

Also under Belgian case law, the claim to exit the company is granted if the dismissal of a director is the consequence of abuse of the majority position of a shareholder $^{34}$. Hence, a majority shareholder, who abuses his controlling voting power to dismiss quite suddenly a director from the manager's board, cannot expect that this ex-director remain a shareholder ${ }^{35}$.

Serious grounds are assessed on account of the petitioning shareholder who wants to exit. To justify an exit, the dismissal as a managing director has to be unreasonable, in which case the unreasonable dismissal does not have to violate the company's interests nor the functioning of the undertaking.

Notwithstanding specific circumstances, an exit proceeding of a shareholder is granted when he is dismissed as a director and the majority shareholder brings the negotiations for a transfer of shares to a halt on a discretionary way ${ }^{36}$. 


\section{Case Compared: Tunneling and Freeze-Out}

Suppose that a majority shareholder takes advantage of his position and exercises his voting power in order to arrange the transfer of some assets out of the company for his own benefit ${ }^{37}$. Furthermore, the majority shareholder abuses his controlling voting power at the expense of the minority shareholder through a minority freeze-out ${ }^{38}$ : Profits are not distributed to the shareholders while the director's remuneration increases and evaporates all profits of the company. As a consequence, the value of the shares declines and returns on the investment of the minority shareholder are withheld.

English courts have held the diversion of the assets of a company or the claim for excessive remuneration to be unfairly prejudicial.

In the case of $\operatorname{Re}$ Cumana $^{39}$, one of the shareholders, Bolton held two thirds of the shares of the company, while the other shareholder, Lewis, held one third of the shares. The two shareholders informally agreed that Bolton was a director of the company, unlike Lewis, but would inform Lewis about the major decisions in the company's affairs. They negotiated that the profits would be divided in proportion to the shareholdings. Though, Bolton claimed excessive remuneration without mentioning it to Lewis. Moreover, Bolton diverted some of the assets to another company without a good commercial reason. Above all, Bolton knew that Lewis was financially unable to take up his proportion of shares and used his controlling voting power to increase the capital. The circumstances were held to constitute a freeze-out and to be unfairly prejudicial to the interests of Lewis.

Similarly to the English judgment is the Dutch judgment in the Metz case ${ }^{40}$. In this case, Metz Sr., Metz Jr., and three other family members held shares of a Besloten Vennootschap. The company owed a debt to Metz Sr. and Metz Jr., the majority shareholders, at a rate of $12 \%$, far beyond the market rate while it was not entirely clear why the company needed this loan. Obviously, this is a case of tunneling. Furthermore, Metz Sr. and Metz Jr. rewarded huge bonuses that did not correspond with the profits of the company. When Metz Sr. and Metz Jr. did not provide proper information about the company's value during the negotiation for a voluntary sale, the other family members requested for the purchase of their shares by means of an exit proceeding. Finally, the court held that the continuation of the other family members' shareholdings could no longer reasonably be expected and authorized the buy-out.

Also under Belgian case law, the claim to exit the company is granted if the directors, appointed by the majority shareholder, are rewarded an excessive remuneration while the minority shareholder does not receive sufficient information about what the directors do in return ${ }^{41}$. It is not required that a minority shareholder proves the detriment is already caused: Running a risk that the amount of remuneration is as large as to affect the distribution of dividend grounds the claim to exit a company.

\section{Conclusion}

The theoretical framework suggests that the facts considered as unfair prejudice or serious grounds to exit differ. Nevertheless, the comparison of two similar cases shows that the protection of minority shareholders is more or less the same.

First and foremost, the open words "unfairly prejudicial", "When the interests of a shareholder are prejudiced to such an extent that the continuation of his shareholding can no longer reasonably be expected from him", and "serious grounds" give the exit proceeding an open character. Hence, the exit proceedings are not limited to the categories "unreasonable dismissal as a director”, “tunneling”, and “freeze-out", listed above. Despite the other terms, in none of the legal systems "precise boundaries of protection" 42 are afforded by the compulsory buy-out of a minority shareholder. 
At first sight, the field of application of the compulsory buy-out seems broader under Dutch and Belgian law: Also a breach of confidence is taken into account and the Belgian case law emphasizes on the interests of all shareholders and on the idea that the functioning of the undertaking or company's interests may not be harmed while the interests of a minority shareholder are. However, it is observed under English law that the word "interests" is much broader than "legal rights" ${ }^{43}$. In a private limited company or a quasi-partnership, however, interests contain not only the legal rights determined in the memorandum and articles of association, but also any equitable considerations such as legitimate expectations which may arise from informal agreements between shareholders ${ }^{44}$.

The underlying facts of cases may be similar, but the facts are never the same. That is why it is difficult to draw a line in the case law even in one single legal system. And that is why it is so difficult to compare the legal systems. Conclusions may not be drafted too soon, however, taking into account the "equitable considerations" and "legitimate expectations" while examining the unfairness of a prejudice is comparable to the consideration of a "breach of confidence" while examining the serious grounds to exit a company.

Finally, wide discretion is vested in the English, Dutch, and Belgian court in granting relief. If an English court is satisfied that a petition is well-founded, it may make such order as it thinks fit for giving relief in respect of the matters complained of, whereas a Dutch and Belgian court may or may not grant a shareholder's claim to exit.

\section{CHAPTER 2-HOW DOES THE COURT ASSESS THE FAIRNESS OF THE PRICE TO BE PAID FOR THE COMPULSORY TRANSFERRED SHARES}

An English, Dutch, and Belgian court may order the buy-out of a minority shareholder. Consequently, the court has to determine the price of the shares concerned. However, the "Unfairness does not lie in the exclusion alone but in exclusion without a reasonable offer" ${ }^{\text {"45 }}$. The English, Dutch, and Belgian procedures only achieve the social objective of protecting the (patrimonial) interests of a minority shareholder, if the court assesses the fairness of the price to be paid for the compulsory transferred shares. Seven different factors may have an impact on the value of the shares.

\section{Valuation Clauses in the Articles of Association or Shareholder's Agreement}

A first issue concerns the valuation clauses in articles of association or shareholders' agreement. Given that the articles of association must be adopted unanimously, and thus with approval of a minority shareholder, it is more likely that clauses in the articles of association or shareholder's agreement are protecting the (patrimonial) interests of a minority shareholder to a reasonable extend ${ }^{46}$.

English courts have taken different views on how such valuation clauses should be dealt with. In former cases, courts were of the opinion that the agreed valuation mechanism could be applied and could provide a bar for a petition under the sections of the unfair prejudice procedure ${ }^{47}$. However, since the unfair prejudice procedure creates personal rights and applies automatically to all companies, provisions cannot limit the entitlement of members to petition under the unfair prejudice procedure ${ }^{48}$ or the possibility to obtain a fair offer for the shares transferred. In more recent cases, it is held that there is nothing unreasonable in the petitioner refusing to accept the risk that his shares would be valued at a discount, because of the minority character of his shares ${ }^{49}$. When a provision contains a valuation mechanism involving the risk of application of a minority discount, the valuation mechanism is not applied and shareholders have the possibility to petition in case of "unfair prejudice". 
However, valuation clauses contained in the articles of association of a Dutch private limited company, or in an agreement, must take precedence over the valuation process in the exit proceeding ${ }^{50}$. In the exit proceedings, one or more experts are authorized to advice on the value of the shares ${ }^{51}$. The valuation process laid down in a statutory provision or contractual clause may limit the discretionary power of the experts ${ }^{52}$.

By contrast, it is held several times by the Belgian courts that the right to petition under articles 340 and 341 Belgian Companies Code is an inalienable right. Hence, the exit proceedings have a mandatory character. The parties' agreement which included the clause that disputes between shareholders should be brought before an arbitration court, cannot remove or diminish the right to start a petition in case of serious grounds in order to exit the company ${ }^{53}$.

The legislation does not stipulate how the matter is to be approached, however, this comparison shows that the English, Dutch, and Belgian courts hold another view. Under English law, a quasi-partnership is the precondition to exclude the possibility of discount. Furthermore, the line is drawn between management and passive investment only. On the other hand, the Dutch courts never apply a discount, whereas the Belgian courts take different approaches.

\section{Appointment of a Valuation Expert}

The second issue concerns the appointment of a valuation expert. The value of the shares may be influenced by who examines the value of the shares.

Under English law, the parties are free to appoint a valuation expert based on mutual understanding. When the parties do not agree on who will be appointed, the court should appoint a valuation expert $^{54}$. The court may also value the shares based on evidence given at trial, such as existing expert reports ${ }^{55}$.

Contrary to the former legal provision, a Dutch court is no longer legally obliged to appoint one or more experts in order to advice on the value of the shares. The court may also value the shares based on evidence given at trial, such as existing expert reports $^{56}$.

Also Belgian courts may appoint an expert to advice on the value of the shares by way of a written report. Although a court is not bounded to a valuation report, the court usually determines the price of the shares on the basis of this expert report by way of judgment ${ }^{57}$.

This comparison sets out to determine that the English rule to appoint an expert on the initiative of the parties, is the best way to achieve the social goal, willing to give a fair procedure to all shareholders.

\section{Discount or Pro Rata Parte to the Total Value of the Company}

A third question is whether a petitioner's minority shareholding should be valued pro rata to the total value of the enterprise or whether its value should be discounted if it appears to be a minority shareholding. However, in the real world, the value of a minority shareholding in a private limited company ("what a third party wants to pay") is usually much less than the pro rata value because these shares have no influence on the decision-making process ${ }^{58}$.

Under English law, there is a strong presumption that in the case of quasi-partnerships, no such discount should be applied ${ }^{59}$. To put the matter another way, when a private limited company fulfills the elements of a quasi-partnership let down in Ebrahimi v. Westbourne Galleries Ltd, the English court tends to favor an undiscounted value of the shares of the private limited company. Therefore, the prime concern in deciding whether to apply a discount is whether the minority shareholder participates in the conduct of the company's affairs or holds his shares purely as a form of investment ${ }^{60}$. Moreover, when the petitioner originally bought the shares at a price which was discounted to reflect their minority status, it is appropriate to apply a discount. 
This is not to say that there may not be cases in which it will be fair to take a discounted value. The exception to the no discount practice is when the petitioner is in case of a petitioner's misconduct. In the event that the responders have established that the petitioning minority shareholder has acted in such a way as to deserve his exclusion from the company a discount may be applied ${ }^{61}$.

Besides that, Dutch courts do not apply a discount when the compulsory transferred shares constitute a minority holding. The Dutch legal doctrine is also of the opinion that a nuisance value of a minority stake or the fact that the shares are not easily transferable should be disregarded ${ }^{62}$. As a result, the effect of control within a company is neutralized. The Dutch New Civil Code contains the provision that all shares shall rank in an equal rate in proportion to their amount ${ }^{63}$. That is why the pro rata parte of shares is always taken into consideration.

On the other hand, there is not one rule that can be applied in Belgium. The legislation does not stipulate how the matter is to be approached, and up till now, some courts decide to apply a discount ${ }^{64}$ and others do not. Furthermore, the Belgian doctrine is divided. Some authors pay more attention to the protection of the minority shareholder. Equally, if the order provided for the purchase of the majority shareholder, there should be no premium to reflect the holding's majority status. The other group of authors lays stress on the comparison with shares of a company listed on a stock exchange and decides that the market value of the minority shareholding is much less than the pro rata parte value ${ }^{65}$.

It does not need to be said that a price without discount is the best for achieving the social goal of protecting the (patrimonial) interests of a minority shareholder. However, the comparison has shown that the English, Dutch, and Belgian case law are poles apart. The Dutch courts will never apply a discount, whereas English courts examine whether or not the company is a quasi-partnership and take into account the conduct of the petitioner. On the other hand, Belgian courts regularly value the shares at on discounted basis to reflect the fact that it is a minority holding.

\section{Going Concern Basis or Net Assets Basis}

Since the English unfair prejudice remedy is an alternative to the dissolution of the company, a demand of valuing the compulsory transferred shares on a net assets basis is rejected ${ }^{66}$, unless the company plans to liquidate shortly after the unfair prejudice procedure. Usually the valuation on a net assets basis or liquidation basis produces an even lower price than a price with discount on a going concern basis ${ }^{67}$. Moreover, when the defendant or purchaser of the shares intends to carry on the business, the valuation on a net assets basis would give him "a windfall at the expense of the seller"68.

Proceedings for the settlement of disputes between shareholders aim at avoiding the company's dissolution. Therefore, also the Dutch and Belgian ${ }^{69}$ case law reject a valuation on a net assets basis.

\section{Valuation Date}

A fifth issue concerns timing. The value put on shares will depend on when the value of the enterprise is assessed: Before or after the shareholders dispute took place, with or without the impact of the unfair prejudice or serious ground.

The English courts are faced with the issue of deciding which date is made from a fairness point of view $^{70}$ : The date of the unfair prejudice, the date the petition is filed under section 994 Companies Act $2006^{71}$ or the date when the purchase order is made ${ }^{72}$. However, to ensure that a minority shareholder receives a fair value, the courts examine the date on a case-by-case basis. Furthermore, courts usually reject the average of a two-stage valuation, even if this includes "the possibility of a rough edge for one side or the other compared with a more elaborate procedure" $^{, 73}$. 
Under Dutch law, the shares have to be valued with reference to the day on which the judgment rewarding the exit claim becomes irrevocable ${ }^{74}$. Furthermore, a court must also take into regard fluctuations of the price occurred after the valuation date $^{75}$.

The leading thought in Belgian case law is that the shares are valued with reference to a day that approaches the day on which the shares are actually transferred $^{76}$. On this date, the shares will be for the account and risk of the person ordered to accept the shares. A court may not consider fluctuations of the price occurred after the valuation date if the fluctuation is due to the conduct of one of the shareholders.

This comparison sets out to determine that under English case law, a flexible date is more accepted than under Dutch and Belgian case law. In the author's opinion, a flexible date is the best way to achieve the social goal, willing to give a fair procedure to all shareholders: On a case-by-case basis, a minority shareholder may receive a fair value. Why? An earlier valuation shall be better if the miscount has reduced the value of the company.

\section{Valuation Method to Obtain the Fair Value of the Shares}

The sixth factor that may influence the value of the shares transferred concerns the valuation method.

Under the unfair prejudice procedure, shares are priced at a "fair" value. What is fair "may often be generally predicated in regard to matters of common occurrence, it can never be conclusively judged in regard to a particular case until the facts are known"77. In other words, there are several methods to arrive at a "fair value" (market value, discounted cash flow, earnings value, comparison with comparable corporations, combination of methods), but one may not tell which will best reflect the fair value of the shares.

Like under English law, the Dutch legal system does not provide guidelines for valuation methods. The determination of the price of shares for which no liquid market exists depends on the circumstances of the $\operatorname{case}^{78}$. However, the first draft contained the provision that Dutch experts have to report about "the value of the shares in the economic market", equal to the value of the shares in a voluntary sale and purchase $^{79}$.

Also the Belgian commercial courts have to assess the "objective" value of the shares transferred without a statutory prescription. In practice, courts or experts mostly choose a few valuation methods and average them to achieve a fair value of the shares. In order to estimate the value in function of the undertaking, his specific features and the facts of the case, courts may apply a weighting factor ${ }^{80}$.

Since valuation itself is an extremely complicated issue which could not be extensively be addressed in this paper, it is difficult to draw any conclusions. Nevertheless, with regard to the question "how to guarantee that a compulsory buy-out is also a social measure", it is important to notice that if the price is set below the value of the shares in the economic market, consequently, the exitting shareholder is in a less favorable position than if he sells the shares voluntarily. From the defending shareholder's point of view, the price set below the value of the shares in the economic market will not give him "a windfall at the expense of the seller”.

\section{Reflective Loss}

The last question is whether or not a shareholder can personally sue for loss that is reflecting loss of the company. Reflective loss concerns the decrease of the value of the shares if and for as far as the decrease is a consequence of loss caused to the company ${ }^{81}$.

In English company law, the compensation for damages should be considered in adjusting the value of the shares transferred in an unfair prejudice proceeding because the minority shareholders' leaving 
at undervalue will be an incentive for the majority to oppress the minorities ${ }^{82}$. But the ability of the English court to reward personal relief for a wrong done to the company has been criticized: There is a possibility that the company goes bankrupt and the deterioration of the potential claim may affect the position of creditors $^{83}$.

Because proceedings for damages seldom lead to compensation for a decrease in value of the shares, and considering that the decrease is often caused by the defending shareholder in an exit proceeding, the Dutch court may increase the price of shares in order to compensate reflective loss ${ }^{84}$.

In contrast, in Belgian company law, it is established that a shareholder cannot personally sue for loss that is reflecting loss of the company ${ }^{85}$.

\section{CONCLUSIONS}

The social objective to protect the (patrimonial) interests of minority shareholders is not easy to achieve. Making the exit proceeding a social remedy giving all shareholders a fair procedure, is a struggle for the British, Dutch, and Belgian judges.

In the renowned article "Filling Gaps in Incomplete Contracts”, I. Ayres and R. Gertner provide a theory of how courts and legislatures should set up default rules ${ }^{86}$. Contracts are incomplete because the transaction costs for concluding on every contingency are higher than the benefits. Furthermore, shareholders do not foresee the contingency of a serious and long-lasting conflict between them, when they do not know yet that all that glistens is not gold.

That is why legislators and judges have to fill in the gaps in contracts and choose the default that most parties would have contracted for.

In the author's view, the English unfair prejudice and the Dutch and Belgian (exit) proceeding for the settlement of disputes between shareholders, in essence, encompass the same principles, although the English, Dutch, and Belgian judges sometimes filled in the gaps in another way.

Firstly, although the terminology of "unfair prejudice", "When the interests of a shareholder are prejudiced to such an extent that the continuation of his shareholding can no longer reasonably be expected from him", and "serious grounds" differs, the proceedings have the same ratio legis: the proceedings aim at avoiding a company's dissolution and improving the protection the (patrimonial) interests of minority shareholders. Moreover, these proceedings endorse wide discretion for the court to consider the facts.

Secondly, all three jurisdictions struggle with the question how to strike a balance between legal certainty and principles of corporate law at the one hand, and the discretion of the court and legitimate expectations of a shareholder at the other hand. Not only a fault or abuse of a majority shareholder is taken into account, but also a "breach of confidence" or "legitimate expectations guaranteed by informal agreements".

Thirdly, regarding the valuation issues, the practice in England, the Netherlands, and Belgium differs from each other, besides the consensus on a valuation on a net assets basis and the valuation methods. As to the discount, a pro rata valuation is widely accepted under English and Dutch law and less frequently applied under Belgian law.

The advantages of the Dutch exit proceedings are the consideration of valuation clauses contained in the articles of association, the possibility of taking into regard fluctuations of the price occurred after the valuation date and the possibility to increase the price of the shares in order to compensate reflective loss. Therefore, with regard to the achievement of the social objective, the Dutch exit proceedings gain an advantage over the English and Belgian procedures.

\section{Notes}

1. Ebrahimi v Westbourne Galleries (1972) 2 WLR 1289. 
2. Statement of the Commission to the European Parliament and others 12/12/2012, COM (2012) 0740 final, 13, Action Plan: European company law and corporate governance-a modern legal framework for more engaged shareholders and sustainable companies, http://eurlex.europa.eu/ legalcontent/EN/ALL/;jsessionid=pwGDTvhSDn1l6RTXv Z6xz53Hc111jB2xhMhQwjBLcGPTZnWWsywd!6323339 48?uri=CELEX:52012DC0740.

3. The Dutch and Belgian legislators have also introduced the expulsion proceeding for the settlement of disputes between shareholders. In most cases, the expulsion proceeding is introduced by a majority shareholder who wants to exclude a minority shareholder. It is beyond the scope of this paper to compare the Dutch and Belgian expulsion proceedings.

4. In this paper, "private limited company" stands for the following closed companies: private company with limited shares in English law and her counterparts, the Besloten Vennootschap in Dutch law, and the Besloten Vennootschap met Beperkte Aansprakelijkheid in Belgian law.

5. Commission Staff Working Document on the implementation of Commission Recommendation of May 6, 2003 concerning the definition of micro, small and medium-sized enterprises, SEC (2009) 1350 final, October 7, 2009.

6. Communication from the Commission to the Council, the European Parliament, the European Economic and Social Committee and the Committee of the Regions- "Think Small First"-A "Small Business Act" for Europe, COM (2008) 0394 final, 25.06.2008, 6.

7. P. P. Davies and S. Worthington, Principles of Modern Company Law, Sweet \& Maxwell, London, 2012, 743, 20-37.

8. S. Girvin, S. Frisby, and A. Hudson, Charlesworth's Company Law, 18th edition, London, Sweet \& Maxwell, 2010, p. 505.

9. L. Sealy and S. Woringhton, Sealy's Cases and Materials in Company Law, 9th edition, Oxford, Oxford University Press, 2010, p. 595.

10. H.-J. de Kluiver and J. Roest, "Expulsion and Withdrawal of Shareholders”, in D. F. M. M. Zaman, The European Private Company (SPE), a Critical Analysis of the EU Draft Statute, Antwerp, Intersentia, 2009, 66, No. 2.

11. Unlike under Belgian law, a shareholder may also order the transfer of his shares to the company itself under Dutch law.

12. Idem Note 11.

13. Proposal for law amending the law on commercial companies, Parliamentary document Chamber 1992-1993, No. 1005/1, 15 (Belgium).

14. Section 994-996 Companies Act 2006.
15. A statistical survey on section 944 petitions in the period as from January 1994 to December 1995 shows that 96\% of the petitions relate to shareholders in an ltd, while $4 \%$ of the petitions relate to shareholders of public limited companies. Law Commission, Shareholder Remedies, Consultation Paper No. 142, London, Stationary Office 1996, appendix E statistics, p. 236.

16. Section 994 till 996 Companies Act 2006.

17. Ebrahimi v Westbourne Galleries (1972) 2 WLR 1289, 2 All ER 492, 500.

18. Articles 2:335 until 2:343cc Dutch New Civil Code.

19. H. T. Verhaar, "De verbeterde geschillenregeling: meer potentieel dan wellicht wordt gedacht”, Onderneming en financiering 2012 (20), 30.

20. P. van Schilfgaarde, "Hoofdlijnen van het nieuwe Antilliaanse NV-en BV-recht”, in P. Van Schilfgaarde and others, Vereenvoudiging en flexibilisering van het Nederlandse BV-recht, Deventer, Kluwer, 2005, 12.

21. Article 2:207 Dutch New Civil Code.

22. One (or more) shareholder(s), holding at least $1 / 3$ th of the share capital of the company can demand the court to expel a shareholder on the basis of serious grounds following which he prejudices the interest of the company to such an extent that the continuation of his shareholding can no longer reasonably be tolerated. The serious grounds must violate the company's interests.

23. Articles 334 until 342 Belgian Companies Code.

24. The author conducted an interview with the President of the Commercial Court of Antwerp Greta Thibaut.

25. I. Corbisier, "Actualité récentes en droit des sociétés: résolution des conflits entre associés (pour les petites) et corporate governance (pour les grandes)", DAOR Actualiteit/actualité 2000-01, 7.

26. A quasi-partnership is an association based on a personal relationship, with a formal or informal agreement that all shareholders shall participate in the management and a restriction on the transfer of shares, so that a shareholder cannot take out his stake and go elsewhere. Strahan v Wilcock (2006) EWCA Civ 13, (2006) BCC, 320, CA, see also P. P. Davies and S. Worthington, Principles of Modern Company Law, Sweet \& Maxwell, London, 2012, 742, 20-36.

27. O’Neill v Phillips, (1999) 2 BCLC 1.

28. Larvin v Phoenix Office Supplies Ltd (2002) EWCA Civ 1740.

29. Grace v Biagioli (2006) 2 BCLC 70. In the same way: Home \& Office Fire Extinguishers Ltd, Re (2012) EWHC917.

30. J. M. M. Maeijer, G. van Solinge, M. P. Nieuwe Weme, Mr. C. Asser's handleiding tot beoefening van het Nederlands burgerlijk recht, Rechtspersonenrecht, De naamloze en 
besloten vennootschap, Deventer, Kluwer, 2009, 904, No. 709.

31. Sign Top, Court of Utrecht 25th June 2008, JOR 2008, 228.

32. Hooymans, Enterprise Chamber of the Court of Appeal of Amsterdam 20th November 1997, JOR 1998, 26, NJ 1998, 392.

33. Ruitenberg NV v STAK Ruitenberg, Court of Zutphen 25th April 2012 (HA ZA 11-828), JOR 2012, 179.

34. President Commercial Court Tongeren 4th October 2005, RABG 2009, 126, JDSC 2009, 319, TRV 2011, 50, note M. Roelants.

35. President Commercial Court Tongeren 5th November 2002, TRV 2004, 383.

36. Court of Appeal of Brussels 18th February 2002, RW 2003-2004, 1467

37. This type of oppression is called "tunneling". S. Jhonson, R. La Porta, F. Lopez-De Silanes, and A. Shleifer, “Tunneling”, American Economic Review Papers and Proceedings 2000, 22-27, No. 90.

38. A freeze-out may exist of a wrongful diversion of company business, an attempt to reduce a shareholder's proportional stake in the company or an excessive remuneration. The amount of remuneration to be set is at the board's discretion. The amount has to be "proportionate", which remains a vague term.

39. Re Cumana Ltd (1986) BCLC 430.

40. Metz, District Court of Rotterdam, 5th November 1998, JOR 1999, 28.

41. President Commercial Court Kortrijk 10th July 1997, JDSC 2000, 358, V\&F 1997, 326.

42. Saul D Harrison, (1995) 1 BCLC 14.

43. Re Sam Weller \& Sons Ltd (1990) BCLC 80, (1990) Ch. 682, Chancery Division.

44. Saul D Harrison (1995) 1 BCLC 14.

45. O’Neill v. Phillips (1999) 2 BCLC 1.

46. In the case that the valuation clause does prejudice the (patrimonial) interests of a minority shareholder, the shareholder can blame himself for approving the articles of association or the shareholders' agreement.

47. Re XYZ Ltd (1987) BCLC 94; Re a Company (No. 007623) (1986) BCLC 362.

48. B. R. Cheffins, Company Law: Theory, Structure and Operation, Oxford, Oxford University Press, 1997, 260.

49. Re a Comany (No. 00330 of 1991) ex p. Holden (1991) BCLC 597; Virdi v Abbay Leisure Ltd (1990) BCLC 342.

50. Article 2:337, 1st paragraph Dutch New Civil Code; Parliamentary Papers II 2006/07, 31 058, 24-25, No. 6.

51. Article 2:339, 1st paragraph Dutch New Civil Code.

52. G. C. Van eck, "Naar een eigen statutaire geschillenregeling op maat”, in C. D. J. Bulten, G. C. van Eck, H. M. de Mol van Otterloo, and J. H. M. Willems, De nieuwe geschillenregeling, preadvies van de vereeniging handelsrecht 2011, Deventer, Kluwer, 2011, n1, 47.

53. Court of Appeal of Brussels 6th February 2001, RW 2001-02, 1573; Court of Appeal of Brussels 20th April 1999, TRV 1999, 432; President Commercial Court of Mons 16th March 2001, RPS 2003, 187, TBH 2001, 629, TRV 2001, 421; E. Janssens, “De waardering van aandelen nav een uitsluiting of uittreding van aandeelhouders in een $n v$ ”, TRV 2001, 366-367; S. Gilcart, “Les articles 190ter et 190quater des lois coordonnées sur les sociétés commerciales: réflexions sur les deux nouvelles procédures de résolution des conflits entre associés”, RRD 1997, No. 83, 277.

54. A. J. Boyle, Minority Shareholders' Remedies, Cambridge, Cambridge University Press, 2004, 106.

55. V. Josse, D. Drake, G. Richardson, and D. Lightman, Minority Shareholders, Law, Practice and Procedure, Oxford, Oxford University Press, 2008, 283.

56. Hoffman Hoge Raad 21th January 2005, NJ 2005, 57.

57. Court of Appeal of Brussels 7th April 2006, TBH 2006, 1035; Court of Appeal of Antwerp 27th January 2005, TBH 2006, 441; B. Verkempinck, "Prijsbepaling van aandelen in de geschillenregeling: na vijftien jaar nog steeds een hemeltergend raadsel voor de initiatiefnemende aandeelhouders", DAOR 2011, 341; M. ROELANTS, "De rechter rekent zelf bij de uittreding van een aandeelhouder", TRV 2011, 45; K. Geens and T. Verhoest, "Développementsrécents dans la matière des procédures de sortie prévues par les articles 190ter en 190quater des loiscoordonnées”, RPS 1998, 358.

58. R. Hollington Q. C., Shareholders' Rights, Sweet \& Maxwell, London, 2004, 247, 8-43.

59. Strahan v. Wilcock (2006) All ER (D) 106; IEWCA Civ 13 (2006) B. C. C. 320; Irvine v. Irvine (2006) EWHC 583; Richards v. Lundy (1999) B.C.C. 786; Quinlan v. Essex Hinge Co Ltd (1997) B.C.C.53; Re Castleburn Ltd (1989) 5 B.C.C. 652; Re Bird Precision Bellows Ltd (1986) Ch. 658; Re Bird Precision Bellows Ltd (1984) 1 Ch 419, (1984) 3 All ER 444, (1984) 2 WLR 869 and the speech of Lord Hoffmann in O'Neill v Phillips (1999) 2 All ER 961, (1999) 1 WLR 1092, at 1107, (1999) 2 BCLC 1: "The Law Commission (paragraphs 3.57-62) has recommended a statutory presumption that in cases to which the presumption of unfairly prejudicial conduct applies, the fair value of the shares should be determined on a pro rata basis. This too reflects the existing practice. This is not to say that there may not be cases in which it will be fair to take a discounted value. But such cases will be based upon special circumstances and it will seldom be possible for the court to say that an offer to buy on a discounted basis is plainly reasonable, so that the petition should be struck out”. 
60. The line is drawn between management (no discount applied) and investment (discount applied). The court should also bear in mind that a purely investment can change into a participation in the conduct of the company's affairs and vice versa. Strahan v Wilcock (2006) EWCA Civ 13, (2006) BCC, 320, CA, see also P. P. Davies and S. Worthington, Principles of Modern Company Law, Sweet \&Maxwell, London, 2012, 742-743, 20-36, and 20-37.

61. Irvine v. Irvine (2006) EWHC 583, 5th paragraph.

62. C. D. J. Bulten, De geschillenregeling ten gronde, Deventer, Kluwer, 2011, 200; P. P. De Vries, Exit rights of minority shareholders in a private limited company, Deventer, Kluwer, 2010, 339-340.

63. Article 2:201 Dutch New Civil Code. S. W. van den Berg, "De blokkeringsregeling, prijsbepalingsregels en waarderingsdilemma's voor waarderingsdeskundigen”, Ondernemingsrecht 2013, 574.

64. Court of Appeal of Antwerp 23th October 2000, TRV 2001, 388-392, note E. Janssens.

65. B. Verkempinck, "Prijsbepaling van aandelen in de geschillenregeling: na vijftien jaar nog steeds een mysterium tremendum”, DAOR 2011, 372; K. Geens and T. Verhoest, "Dévelopments récents dans la matière des procédures de sortie prévues par les articles 190ter et 190quater des Lois Coordonnées”, RPS 1998, 362.

66. Re Bird Precision Bellows (1984) Ch 419 (at 428).

67. Re Elgindata Ltd (1991) BCLC 959.

68. CVC/Opportunity Partners v Demarco Ameida (2002) BCLC 108 (at 38).

69. Court of Appeal of Antwerp 27th January 2005, TBH 2006, 441, No. 3.

70. Re London School of Electronics Ltd (1985) BCLC 273.

71. Re a Company (No. 002612, 1984) (1986) 2 BCC 99, 492-499 (at p. 453); SCWS v. Meyer (1959) AC 324, 369.

72. Profinance Trust SA v Gladstone (2002) 1 BCLC 141 (at 160).

73. O’Neill v. Phillips (1999) 1 WLR 1092, 1107(H. L.).

74. Parliamentary Papers II 2006/07, 31 058, 104, No. 3.

75. Aannemersbedrijf Gebroeders Sonder, Enterprise Chamber of the Court of Appeal of Amsterdam 5th August 2004, JOR 2004, 327 (at 4.7.).

76. Court of Cassation 9th December 2010, JT 2011, 886, JLMB 2011, 1656, Pas. 2010, 3165, JDSC 2011, 239, ТВH 2011, 259, TBH 2012, 22.

77. Re Bird Precision Bellows (1986) Ch 658; Re Bird Precision Bellows (1984) Ch 419.

78. Zeevisser, High Court 2th March 2001, NJ 2001, 584 (at 3.3).

79. J. M. M. Maijer, G. van Solinge, M. P. Nieuwe Weme, Mr. C. Asser's handleiding tot beoefening van het Nederlands burgerlijk recht, Rechtspersonenrecht, De naamloze en besloten vennootschap, Deventer, Kluwer, 2009, No. 717.

80. Court of Appeal of Genth 17th March 2003, JDSC 2006, 244, TRV 2004, 367; Court of Appeal of Genth 19th October 2009, JDSC 2012, 238, TRV 2011, 40; Court of appeal of Brussels 18th February 2002, RW 2003-04, 1467; President Commercial court of Genth 14th March 2000, JDSC 2001, 303, TBH 2000, 392, TBH 2001, 755; E. Janssens, "De waardering van aandelen n.a.v. een uitsluiting of uittreding van aandeelhouders in een N.V.", TRV 2001, 367.

81. M. J. Kroeze, Afgeleide schade en afgeleide acie, (dissertation Utrecht), Deventer, Kluwer 2004, 379.

82. Sandford v. Sandford Courier Service Pty Ltd (1987) 11 ACLR 373; Scottish Co-operative Wholesale Society Ltd V. Meyer (1959) AC 324.

83. H. C. Hirt, "In what circumstances should breaches of director's duties give rise to a remedy under ss. 459-461 of the companies act 1985”, The Company Lawyer 2003, 109; H. C. Hirt, "Companies in General, In what circumstances can a shareholder succeed with a claim for reflective loss? The Court of Appeal in Giles v Rhind”, Journal of Business Law 2003, 429; A. Alcock, “CVC/Opportunity Partners-Do We Really Need Sections 459-461?”, Journal of Business Law 2002, 570.

84. New article 2:343, paragraph 4 Dutch New Code Civil; Parliamentary Papers II 2006/07, 31 058, 111, No. 3.

85. Court of Cassation 23th February 2012, Pas. 2012, 431, RW 2011-12, 1658, TBH 2013, 875, TRV 2012, 319; J. Vananroye, "Aandeelhouders hebben geen zelfstandig vorderingsrecht voor afgeleide schade”, TRV 2012, 322; E. Janssens, "De waardering van aandelen n.a.v. een uitsluiting of uittreding van aandeelhouders in een $N V$,, TRV 2001, 370.

86. I. Ayres and R. Gertner, "Filling Gaps in Incomplete Contracts. An Economic Theory of Default Rules”, Yale Law Review, 1989, 87-130.

\section{References}

Boyle, A. J. 2004. Minority Shareholders' Remedies. Cambridge: Cambridge University Press.

Davies, P. P. and S. Worthington. 2012. Principles of Modern Company Law. London: Sweet \& Maxwell.

Delang, N. L. G. M. 2015. "Minority Protection in Proceedings for the Settlement of Disputes Between Shareholders." Social Study 5(6):1-17.

Girvin, S., S. Frisby, and A. Hudson. 2010. Charlesworth's Company Law. 18th ed. London: Sweet \& Maxwell.

Josse, V., D. Drake, G. Richardson, and D. Lightman. 2008. 
Minority Shareholders, Law, Practice and Procedure. Oxford: Oxford University Press.

Sealy, L. and S. Woringhton. 2010. Sealy's Cases and Materials in Company Law. 9th ed. Oxford: Oxford University Press.

\section{Bio}

Nore Delang, LL.M., research assistant, Katholike University, Leuven, Belguim; research fields: company law and family law. 